\title{
Front Matter: Volume 6825
}

, "Front Matter: Volume 6825," Proc. SPIE 6825, Lasers in Material Processing and Manufacturing III, 682501 (21 February 2008); doi: $10.1117 / 12.786360$

SPIE. Event: Photonics Asia 2007, 2007, Beijing, China 


\title{
PROCEEDINGS OF SPIE
}

\section{Lasers in Material Processing and Manufacturing III}

\author{
ShuShen Deng \\ Akira Matsunawa \\ Xiao Zhu \\ Editors
}

12-14 November 2007

Beijing, China

Sponsored by

SPIE

COS-Chinese Optical Society

Cooperating Organizations

OSJ-Optical Society of Japan - OSK_Optical Society of Korea • Australian Optical Society • Optical Society of Singapore $\bullet$ Beijing Institute of Technology (China) $\bullet$ Beijing University of Posts and Telecommunications (China) • Peking University (China) • Tsinghua University (China) • Zhejiang University (China) • Changchun University of Science and Technology (China) • University of Shanghai for Science and Technology (China) • Shanghai Jiao Tong University (China) • Tianjin University (China) Nankai University (China) - Shanghai Institute of Optics and Fine Mechanics (China) • Changchun Institute of Optics and Fine Mechanics (China) • Institute of Semiconductors (China) • Institute of Optics and Electronics (China) - Shanghai Institute of Technical Physics (China) • China Instrument and Control Society • China Solid State Lighting Research and Industry Alliance • Optoelectronics Technology Committee, cos (China)

Supporting Organizations

CAST_China Association for Science and Technology (China) - NNSF_National Nature Science Foundation (China) • The Ministry of Science and Technology (China)

Published by

SPIE

Volume 6825 
The papers included in this volume were part of the technical conference cited on the cover and title page. Papers were selected and subject to review by the editors and conference program committee. Some conference presentations may not be available for publication. The papers published in these proceedings reflect the work and thoughts of the authors and are published herein as submitted. The publisher is not responsible for the validity of the information or for any outcomes resulting from reliance thereon.

Please use the following format to cite material from this book:

Author(s), "Title of Paper," in Lasers in Material Processing and Manufacturing III, edited by

ShuShen Deng, Akira Matsunawa, Xiao Zhu, Proceedings of SPIE Vol. 6825 (SPIE, Bellingham, WA, 2008) Article CID Number.

ISSN 0277-786X

ISBN 9780819470003

Published by

SPIE

P.O. Box 10, Bellingham, Washington $98227-0010$ USA

Telephone +1 3606763290 (Pacific Time) · Fax +1 3606471445

SPIE.org

Copyright (c) 2008, Society of Photo-Optical Instrumentation Engineers

Copying of material in this book for internal or personal use, or for the internal or personal use of specific clients, beyond the fair use provisions granted by the U.S. Copyright Law is authorized by SPIE subject to payment of copying fees. The Transactional Reporting Service base fee for this volume is $\$ 18.00$ per article (or portion thereof), which should be paid directly to the Copyright Clearance Center (CCC), 222 Rosewood Drive, Danvers, MA 01923. Payment may also be made electronically through CCC Online at copyright.com. Other copying for republication, resale, advertising or promotion, or any form of systematic or multiple reproduction of any material in this book is prohibited except with permission in writing from the publisher. The CCC fee code is 0277-786X/08/\$18.00.

Printed in the United States of America.

Publication of record for individual papers is online in the SPIE Digital Library.

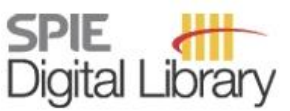

SPIEDigitalLibrary.org

Paper Numbering: Proceedings of SPIE follow an e-First publication model, with papers published first online and then in print and on CD-ROM. Papers are published as they are submitted and meet publication criteria. A unique, consistent, permanent citation identifier (CID) number is assigned to each article at the time of the first publication. Utilization of CIDs allows articles to be fully citable as soon they are published online, and connects the same identifier to all online, print, and electronic versions of the publication. SPIE uses a six-digit CID article numbering system in which:

- The first four digits correspond to the SPIE volume number.

- The last two digits indicate publication order within the volume using a Base 36 numbering system employing both numerals and letters. These two-number sets start with 00, 01, 02, 03, 04, 05, $06,07,08,09,0 \mathrm{~A}, 0 \mathrm{~B} \ldots \mathrm{OZ}$, followed by $10-1 \mathrm{Z}, 20-2 \mathrm{Z}$, etc.

The CID number appears on each page of the manuscript. The complete citation is used on the first page, and an abbreviated version on subsequent pages. Numbers in the index correspond to the last two digits of the six-digit CID number. 


\section{Contents}

ix Conference Committee

xi Symposium Committees

SESSION 1 LASER-INDUCED REMOVAL OF MATERIALS I

682502 Plasma light emission monitoring and penetration status recognition in $\mathrm{CO}_{2}$ laser welding of AZ31B wrought magnesium alloy (Invited Paper) [6825-31]

W. Tan, Tsinghua Univ. (China); J. Shan, Tsinghua Univ. (China) and Key Lab. for Advanced Materials Processing Technology, Ministry of Education (China); X. Lei, J. Zhang, W. Chen, J. Ren, Tsinghua Univ. (China)

682503 Quality control of laser tailor welded blanks (Invited Paper) [6825-42]

Q. Yan, Baoshan Iron and Steel Corp. (China)

682504 Study on process stability and seam characteristics of high power laser welding with filling wire for high thickness steel (Invited Paper) [6825-54]

Y. Cai, G. Li, J. Huang, L. Zhao, Y. Wu, Shanghai Jiao Tong Univ. (China) and Shanghai Key Lab. of Materials Laser Processing and Modification (China)

682505 Laser beam welding of aluminum alloys (Invited Paper) [6825-63]

R. Xiao, Beijing Univ. of Technology (China)

682506 Morphology and mechanical characteristics of pulse laser coating-texturing WC-Ni alloying layers [6825-39]

D. Wan, H. Liu, D. Hu, L. Cai, Shanghai Jiaotong Univ. (China)

682507 Boundary coupled dual-equation numerical simulation on mass transfer in the process of laser cladding [6825-40]

Y. Huang, Y. Yang, G. Wei, South China Univ. of Technology (China); G. Liang, Xi'an Jiaotong Univ. (China)

682508 Mechanism of $\mathrm{CO}_{2}$ laser cutting nonmetallic materials based on wall focusing effects [6825-43]

X. Xie, Guangdong Univ. of Technology (China); L. Li, Hunan Univ. (China); X. Wei, W. Hu, Guangdong Univ. of Technology (China)

682509 A study on laser weldability and formability of high thickness ratio tailor welded blanks [6825-44]

G. Wang, G. Li, Y. Cai, X. Hua, Y. Wu, Shanghai Jiaotong Univ. (China)

$68250 \mathrm{~A}$ Influence of beam spatial distribution on the laser damage of optical material [6825-55]

L. Qi, X. Zhu, C. Zhu, G. Zhu, T. Yang, Huazhong Univ. of Science and Technology (China) 
$6825 \mathrm{OB}$ Laser welding of automobile double-linked gears [6825-59]

Y. Wang, X. Yang, J. Lei, Tianjin Polytechnic Univ. (China); C. Zhao, H. Bi, Tianjin Automobile Gear Factory (China)

\section{SESSION 2 LASER-INDUCED REMOVAL OF MATERIALS II}

6825 OC One-step shaping of NiTi biomaterial by selective laser melting [6825-37]

Y. Yang, Y. Huang, W. Wu, South China Univ. of Technology (China)

6825 OD Ceramics reinforced metal base composite coatings produced by $\mathrm{CO}_{2}$ laser cladding (Invited Paper) [6825-58]

$X$. Yang, Y. Wang, N. Yang, Tianjin Polytechnic Univ. (China)

6825 OF Technological study of oxygen aided laser cutting silicon steel [6825-01]

L. Hong, C. Mi, G. Wu, Shanghai Maritime Univ. (China)

6825 OG Numerical analysis of cutting glass by dual $\mathrm{CO}_{2}$ - laser beams [6825-02]

J. Jiao, X. Wang, X. Zhang, W. Tang, F. Liu, Y. Lu, Huazhong Univ. of Science and Technology (China)

$6825 \mathrm{OH}$ Optimization of laser processing techniques and parameters for laser transformation hardening with multi-objectives [6825-08]

G. WU, L. Hong, Shanghai Maritime Univ. (China)

68250 Ol Fundamental microstructures fabricated on FOTURAN glass using femtosecond laser [6825-13]

Y. Wu, C. Wang, W. Jia, M. Hu, X. Ni, L. Chai, Tianjin Univ. (China)

6825 0J Research of transparent materials bulk damage characteristics by using modulated laser pulse [6825-56]

G. Zhu, X. Zhu, L. Qi, C. Zhu, T. Yang, Huazhong Univ. of Science and Technology (China)

\section{SESSION $3 \quad$ LASER-INDUCED DEPOSITION OF MATERIALS}

6825 OK Femtosecond laser micromachining and microfabrication in transparent materials (Invited Paper) [6825-19]

Y. Li, D. Liu, F. Qi, H. Yang, Q. Gong, Peking Univ. (China)

$6825 \mathrm{OL}$ Selective deposition of conductive copper films on glass surfaces using femtosecond laser surface modification and electroless plating [6825-10]

J. XU, Y. Liao, Shanghai Institute of Optics and Fine Mechanics (China) and Graduate

School of the Chinese Academy of Sciences (China); H. Zeng, East China Univ. of Science and Technology (China); Z. Zhou, H. Sun, Shanghai Institute of Optics and Fine Mechanics (China); J. Song, X. Wang, Shanghai Institute of Optics and Fine Mechanics (China) and Graduate School of the Chinese Academy of Sciences (China); Y. Cheng, Z. Xu, Shanghai Institute of Optics and Fine Mechanics (China); K. Sugioka, K. Midorikawa, Laser

Technology Lab., RIKEN (Japan) 
$68250 \mathrm{M}$ Transparent conducting $\mathrm{CuCr}_{1-\mathrm{x}} \mathrm{Mg}_{\mathrm{x}} \mathrm{O}_{2}$ films prepared by pulsed laser deposition [6825-16] D. Li, X. Fang, R. Tao, W. Dong, Z. Deng, Anhui Institute of Optics and Fine Mechanics (China); X. Zhu, Institute of Solid State Physics (China)

6825 ON Diamond-like carbon films deposited by femtosecond laser pulses [6825-30] Y. Guo, Huazhong Univ. Of Science and Technology (China) and Wuhan Ordnance NonCommissioned Officers Academy (China); X. Yuan, Huazhong Univ. of Science and Technology (China); S. Wang, C. Lu, X. Wang, Y. Cheng, H. Cao, X. Liu, Wuhan Ordnance Non-Commissioned Officers Academy (China)

682500 Improvement of nanosecond laser ablation quality by pulse shaping technique [6825-36] X. D. Wang, Huazhong Univ. of Science and Technology (China); A. Michalowski, Univ. Stuttgart (Germany); S. L. Wang, J. S. Liu, Huazhong Univ. of Science and Technology (China); F. Dausinger, Univ. Stuttgart (Germany)

$6825 \mathrm{OP}$ Research on the filter properties of the one-dimensional three sects photonic crystal with symmetrical structure [6825-48]

Z. Li, X. Tian, H. Wang, T. Zhang, Yanshan Univ. (China)

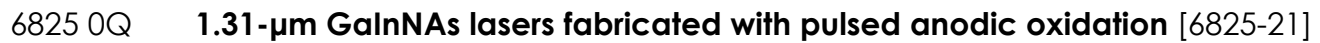

Y. Deng, Y. Qu, Z. Qiao, Changchun Univ. of Science and Technology (China); H. Zou, Jilin Univ. (China); Y. Wang, Z. Li, Changchun Univ. of Science and Technology (China)

\section{SESSION 4 INDUSTRIAL SYSTEMS}

$6825 \mathrm{OW}$ Square laser beam of high power transverse flow $\mathrm{CO}_{2}$ laser and its application [6825-29] Y. Qin, X. Tang, R. Zhong, Z. Li, Huazhong Univ. of Science and Technology (China)

6825 0X Powder flow field distribution with different parameters in coaxial laser cladding [6825-60] N. Yang, X. Yang, Tianjin Polytechnic Univ. (China)

6825 OY Supercontinuum generation in photonics crystal fibers with a femtosecond pulse [6825-49] S. Zhang, X. Meng, G. Zhao, Z. Zhang, Hebei Normal Univ. (China); F. Lu, Nankai Univ. (China); Y. Gong, X. Yang, Institute for Infocomm Research (Singapore)

$6825 \mathrm{OZ}$ A tunable erbium-doped fiber laser with power-equalized output using nonlinear polarization rotation [6825-50]

S. Zhang, D. Li, X. Li, Z. Yang, Hebei Normal Univ. (China)

\section{POSTER SESSION}

682510 Application of the machine CNC system in laser marking [6825-03]

W. Zhao, Tianjin Univ. of Technology and Education (China); Y. Sa, Tianjin Univ. (China);

X. Liu, N. Feng, Tianjin Univ. of Technology and Education (China)

682511 A novel differential optical beam deflection detection system for measuring lasergenerated surface acoustic waves [6825-06]

Y. Shi, Z. Shen, X. Ni, J. LU, Nanjing Univ. of Science and Technology (China) 
682512 Numerical simulation of surface crack detection by laser-generated circumferential guided wave in elastic cylinders [6825-07]

Y. Shi, Z. Shen, X. Ni, J. Lu, Nanjing Univ. of Science and Technology (China)

682513 Mechanical effects during pulsed laser and metals interaction in glycerol-water mixtures [6825-09]

X. M. Liu, J. He, J. LU, X. W. Ni, Nanjing Univ. of Science and Technology (China)

682514 Process investigation of a-Si:H thin films prepared by DC magnetron sputtering [6825-11] C. Liu, Changchun Univ. of Science and Technology (China) and Jilin Normal Univ. (China); C. Wang, Jilin Normal Univ. (China); Y. Yao, Changchun Univ. of Science and Technology (China) and Jilin Normal Univ. (China); J. Zhang, Z. Qiao, B. Huang, Y. Wang, B. Bo,

Changchun Univ. of Science and Technology (China)

682515 Research on the laser lap welding of TC4 titanium alloy and L3 industrial pure aluminum dissimilar metal [6825-14]

S. Liu, J. Ni, X. Zhou, B. Wang, X. Zhang, Huazhong Univ. of Science and Technology (China)

682516 Characteristics of high-peak pulsed laser induced damage to fibers [6825-22]

X. Zhao, Y. Gao, Institute of Electronic Engineering (China); M. XU, W. Duan, H. YU, China Academy of Engineering Physics (China)

682517 Switch power supply of fast axial flow $\mathrm{CO}_{2}$ laser for complex machining [6825-24]

B. Li, Y. Wang, F. Ding, Huazhong Univ. of Science and Technology (China)

682518 Integrated control system of transverse flow $\mathrm{CO}_{2}$ laser and its application [6825-26]

J. Liu, X. Tang, Y. Zhang, H. Peng, Y. Wang, Huazhong Univ. of Science and Technology

(China)

682519 The $\mu \mathrm{c}$-Si on plastic substrate crystallized by pulsed double-frequency YAG laser annealing [6825-32]

J. Li, Z. Meng, Y. Li, C. Wu, Nankai Univ. (China) and Tianjin Univ. (China); H. S. Kwok, The Hong Kong Univ. of Science and Technology (Hong Kong, China); S. Xiong, Nankai Univ. (China) and Tianjin Univ. (China)

68251 A Simulation of thermal stress in $\mathbf{n}$-type diamond thin films prepared by CVD [6825-34] Y. Wang, North China Electric Power Univ. (China); Q. Zhao, Hebei Univ. (China); Z. Zhao, North China Electric Power Univ. (China)

6825 1B Process analysis of diamond ablation by $157 \mathrm{~nm}$ laser [6825-35]

W. Li, D. Jiang, Y. Dai, M. Gao, Wuhan Univ. of Technology (China)

$68251 \mathrm{C}$ Thermal elasto-plastic stress analysis during laser heating of a metal plate [6825-38]

Y. Chen, J. LU, X. Ni, Nanjing Univ. of Science and Technology (China)

6825 1D Mechanical behavior study of laser-welded joints for DP steel [6825-41]

Q. Yan, Baoshan Iron and Steel Co., Ltd. (China) and Shanghai Jiaotong Univ. (China)

6825 IE Study of temperature measurement with one-dimensional photonic crystal [6825-47] H. Wang, K. Tong, W. Cui, Z. Li, Yanshan Univ. (China) 
6825 IF Design of detection system based on laser SAW [6825-51]

X. Feng, C. Chang, Wuhan Institute of Technology (China)

$68251 \mathrm{G}$ A novel material processing and manufacturing measurement system by using electronic datum [6825-61]

W. L. Bear, X.-W. Xiong, Wynn. Bear International Cutting-edge High-Tech Institute, Inc.

(China); J. T. Roth, Pennsylvania State Univ.-Erie (USA); M. P. Schoen, Idaho State Univ. (USA)

682511 Characteristics of $\mathrm{CW} /$ pulse discharge for high power transverse flow $\mathrm{CO}_{2}$ laser and its application [6825-25]

H. Peng, X. Tang, F. Xia, J. Liu, Y. Wang, Huazhong Univ. of Science and Technology (China)

$68251 \mathrm{M}$ Plasma characterization of brass alloys by laser induced breakdown spectroscopy [6825-53]

Y. Li, Y. LU, K. Cheng, J. Wu, R. Zheng, Ocean Univ. of China (China)

$68251 \mathrm{~N} \quad$ Laser remanufacturing technology and its applications [6825-67]

S. Dong, B. Xu, Z. Wang, Y. Ma, W. Liu, National Key Lab. for Remanufacturing (China)

682510 Fabrication of $\mathrm{SiO}_{2}-\mathrm{TiO}_{2}$ strip waveguides by laser direct writing [6825-70]

A. Li, Z. Wang, J. Liu, X. Zeng, Huazhong Univ. of Science and Technology (China);

C. Wang, H. Chen, Institute of Semiconductors (China)

6825 IP Investigation on tribological behavior of Fe-based alloy coating formed by laser cladding [6825-68]

L. Shen, Q. Zhang, J. Song, J. Liao, South China Normal Univ. (China)

$68251 Q \quad$ Control module design for $\mathrm{CO}_{2}$ laser processing system based on WEB protocol [6825-20]

Y. Lu, Y. Wu, Z. Chen, Y. Zheng, H. Chen, R. Chen, Fujian Normal Univ. (China)

Author Index 
Downloaded From: https://www.spiedigitallibrary.org/conference-proceedings-of-spie on 26 Apr 2023

Terms of Use: https://www.spiedigitallibrary.org/terms-of-use 


\title{
Conference Committee
}

\author{
Conference Chairs
}

ShuShen Deng, China Daheng Corporation (China)

Akira Matsunawa, Osaka University (Japan)

Xiao Zhu, Huazhong University of Science and Technology (China)

Program Committee

Yijian Jiang, Beijing University of Technology (China)

Keming Du, EdgeWave GmbH (Germany)

Minlin Zhong, Tsinghua University (China)

Yan Li, Peking University (China)

Günther Weinmann, Consultant (Germany)

Yongfeng Lu, University of Nebraska, Lincoln (USA)

Session Chairs

$1 \quad$ Laser-Induced Removal of Materials I

Xiao Zhu, Huazhong University of Science and Technology (China)

Keming Du, EdgeWave GmbH (Germany)

2 Laser-Induced Removal of Materials II

Akira Matsunawa, Osaka University (Japan)

Yan Li, Peking University (China)

3 Laser-Induced Deposition of Materials

Günther Weinmann, Consultant (Germany)

Yijian Jiang, Beijing University of Technology (China)

$4 \quad$ Industrial Systems

Yongfeng Lu, University of Nebraska, Lincoln (USA)

Xiahui Tang, Huazhong University of Science and Technology (China) 
Downloaded From: https://www.spiedigitallibrary.org/conference-proceedings-of-spie on 26 Apr 2023

Terms of Use: https://www.spiedigitallibrary.org/terms-of-use 


\title{
Symposium Committees
}

\author{
General Chairs \\ Brian Culshaw, University of Strathclyde (United Kingdom) \\ Bingkun Zhou, Tsinghua University (China) and COS-Chinese Optical \\ Society (China) \\ General Cochairs
}

Arthur Chiou, National Yang-Ming University (Taiwan, China)

Mitsuo Takeda, University of Electro-Communications (Japan)

Chungli Bai, Chinese Academy of Sciences (China)

Seung-Han Park, Yonsei University (South Korea)

Zhizhan Xu, Shanghai Institute of Optics and Fine Mechanics

(China)

Jianlin Cao, China Ministry of Science and Technology (China)

Junhao Chu, Shanghai Institute of Technical Physics (China)

Jingming Kuang, Beijing Institute of Technology (China)

Xiaomin Ren, Beijing University of Posts and Telecommunications (China)

Dingbo Kuang, Shanghai Institute of Technical Physics (China)

Guozheng Yang, Institute of Physics (China)

Honorary Chairs

Daheng Wang, Chinese Academy of Sciences (China)

Guoguang Mu, Nankai University (China)

Technical Program Chair

Songlin Zhuang, Shanghai University of Science and Technology (China)

Technical Program Cochairs

Xun Hou, Xian Institute of Optics and Precision Mechanics (China)

Qian Mao, Wuhan Research Institute of Posts and Telecommunications (China)

Xu Liu, Zhejiang University (China)

Local Organizing Committee Chair

Shusen Xie, Fujian Normal University (China)

Local Organizing Committee Cochairs

Guoqiang Ni, Beijing Institute of Technology (China)

Qihuang Gong, Peking University (China)

Ying Gu, PLA General Hospital (China)

Huilin Jiang, Changchun University of Science and Technology (China) 
General Secretary

Guoqiang Ni, Beijing Institute of Technology (China)

Administrative Vice General Secretary

Boyu Ding, Beijing Institute of Technology (China)

Vice General Secretaries

Hanyi Zhang, Tsinghua University (China)

Ya Cheng, Shanghai Institute of Optics and Fine Mechanics (China)

Zhongwei Fan, Academy of Opto-electronics (China)

Jianxin Chen, Fujian Normal University (China)

Lan Wu, Zhejiang University (China)

Shaowen Wang, COS-Chinese Optical Society (China)

Yuejin Zhao, Beijing Institute of Technology (China)

Chongxiu Yu, Beijing University of Posts and Telecommunication (China)

Jun Ruan, China Solid State Lighting Research and Industry Alliance

(China)

Local Organizing Committee Members

Kangnan Qi, Beijing Optical Society (China)

Chunqing Gao, Beijing Institute of Technology (China)

Tiegen Liu, Tianjin University (China)

Lanxing Shao, Shanghai Optical Society (China)

Zaixuan Zhang, Chinese Jiliang University (China)

Hongda Chen, Institute of Semiconductors (China)

Baosheng Liu, Beijing Optical Society (China)

Xin Wang, Hubei Optical Society (China)

Lin Zhai, COS-Chinese Optical Society (China)

Zhiqiang Zhu, East China Normal University (China)

Lei Xu, Fudan University (China)

Hezhou Wang, Zhongshan University (China)

Zhiming Yi, Ofstar Tech Company, Ltd., Shenzhen (China) 